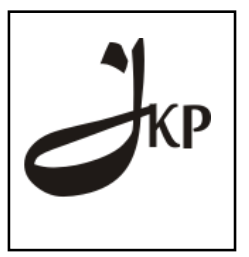

Jurnal Konseling dan Pendidikan

ISSN Cetak: 2337-6740 - ISSN Online: 2337-6880

DOI: https://doi.org/10.29210/119800

http://jurnal.konselingindonesia.com

Volume 5 Nomor 3, 2017, HIm 143-148

Info Artikel:

Diterima 24/09/2017

Direvisi 25/10/2017

Dipublikasikan 30/11/2017

\title{
Konsep Stres Akademik Siswa
}

\author{
Mufadhal Barseli $^{\left.1^{*}\right)}$, Ifdil Ifdil ${ }^{2} \&$ Nikmarijal Nikmarijal $^{3}$ \\ ${ }^{1}$ Universitas Putra Indonesia "YPTK" Padang, ${ }^{2}$ Universitas Negeri Padang, ${ }^{3}$ Indonesian Institute for Counseling, \\ Education and Therapy (IICET) \\ Đe-mail: mufadhalbarseli@konselor.org
}

\begin{abstract}
Abstrak
Siswa yang mengalami stres akademik memiliki persepsi yang maladaptif terhadap tuntutan akademik. Stres akademik adalah persepsi subjektif terhadap suatu kondisi akademik atau respon yang dialami siswa berupa reaksi fisik, perilaku, pikiran, dan emosi negatif yang muncul akibat adanya tuntutan sekolah atau akademik. Hal ini menunjukkan perlu adanya upaya guru Bimbingan dan Konseling atau konselor untuk melakukan pengembangan pada praktik pelayanan Binbingan dan konseling untuk meningkatkan kualitas atau potensi siswa dalam mengantisipasi muculnya stres akademik siswa dan faktor-faktor yang mempengaruhi munculnya stres akademik. Naskah ini akan mengenalkan konsep dasar stres akademik siswa meliputi; konsep stres, konsep stres akademik, faktor yang mempengaruhi stres akademik, gejala-gejala stres akademik, respon stres akademik. Semoga ini dapat digunakan sebagai salah satu rujukan.
\end{abstract}

Kata kunci: stres akademik, siswa

Copyright (C) 2017 IICET (Indonesia) - All Rights Reserved

Indonesian Institute for Counseling, Education and Therapy (IICET)

\section{PENDAHULUAN}

Pendidikan mempunyai arti yang sangat penting bagi kehidupan dan perkembangan siswa. Pendidikan di sekolah dapat memenuhi beberapa kebutuhan siswa dan menentukan kualitas kehidupan mereka dimasa depan. Namun dalam proses pendidikan di sekolah siswa tidak jarang juga mengalami stres karena ketidakmampuannya beradaptasi dengan program di sekolah. Stres yang di alami siswa di lingkungan sekolah akan terakumulasi terhadap gangguan psikologis dan penyakit fisik (Santrock, J. W. 2007; Hidayat, B. U. A. 2012). Stres yang sering dialami oleh siswa adalah stres akademik (Taufik, T., Ifdil, I., \& Ardi, Z. 2013). Stres akademik merupakan sumber stres yang terjadi pada setting sekolah (Calaguas, 2011; Azhar, A. 2015).

Ada beberapa faktor penyebab stres pada siswa yaitu tuntutan akademik yang dinilai terlampau berat, hasil ujian yang buruk, tugas yang menumpuk, dan lingkungan pergaulan. Stres akademik merupakan stres yang termasuk pada kategori distress (Rahmawati, W. K. 2017; Adawiyah, R. 2017). Stres akademik adalah keadaan dimana siswa tidak dapat menghadapi tuntutan akademik dan mempersepsi tuntutan-tuntutan akademik yang diterima sebagai gangguan. Stres akademik disebabkan oleh academic stressor (Sayekti, E. (2017). Academic stressor yaitu stres yang berpangkal dari proses pembelajaran seperti: tekanan untuk naik kelas, lamanya belajar, mencontek, banyak tugas, rendahnyahnya prestasi yang diperoleh, keputusan menentukan jurusan dan karir, serta kecemasan saat menghadapi ujian (Rahmawati, W. K. 2017).

Alvin (dalam Eryanti, 2012) stres akademik adalah tekanan-tekanan yang terjadi di dalam diri siswa yang disebabkan oleh persaingan maupun tuntutan akademik. Senada dengan hal tersebut (Taufik, T., \& Ifdil, I. 2013; Muharrifah, A. 2009) menjelaskan stres akademik muncul ketika harapan untuk meraih prestasi akademik meningkat, baik dari orang tua, guru maupun teman sebaya. Harapan tersebut sering tidak sesuai dengan kemampuan yang dimiliki siswa sehingga menimbulkan tekanan psikologis yang mempengaruhi pencapaian prestasi belajar di sekolah. Selanjutnya menurut Thurson (2005) stres akademik dapat disebabkan 
oleh materi pelajaran yang sulit bagi siswa, sehingga siswa muncul rasa takut terhadap guru yang mengajar. Siswa yang tingkat risiliensi (kemampuan untuk beradaptasi) terhadap stresnya baik dapat memiliki hasil belajar yang bagus. Tekanan dan tuntutan yang bersumber dari kegiatan akademik disebut dengan stres akademik. Lebih lanjut, Misra dan Castillo (2004) menyebutkan bahwa stres akademik meliputi persepsi siswa terhadap banyaknya pengetahuan harus dikuasai dan persepsi terhadap ketidak cukupan waktu untuk mengembangkannya.

\section{Stres}

Stres merupakan suatu kondisi yang disebabkan adanya ketidaksesuaian (Garniwa, I. 2007) antara situasi yang diinginkan dengan keadaan biologis, psikologis atau sistem sosial individu (Sarafino, 2006; Wardi, R., \& Ifdil, I. (2016). (Anggola \& Ongori 2009; Pratama, M. R., 2015; Siska, M., 2011) juga mendefinisikan stres sebagai persepsi dari kesenjangan antara tuntutan lingkungan dan kemampuan individu untuk memenuhinya. Stres merupakan respon individu terhadap keadaan atau kejadian yang memicu stres (stresor), yang mengancam dan mengganggu kemampuan seseorang untuk menanganinya (coping) (Santrock, 2007; Diponegoro, A. M., \& Thalib, S. B. 2001; Dari, P. T. S. D., \& Ibu, D. S. 2012).

Berdasarkan beberapa pendapat di atas, dapat disimpulkan bahwa stres adalah tekanan yang terjadi akibat ketidaksesuaian antara situasi yang diinginkan dengan harapan, di mana terdapat kesenjangan antara tuntutan lingkungan dengan kemampuan individu untuk memenuhinya yang dinilai potensial membahayakan, mengancam, mengganggu, dan tidak terkendali atau dengan bahasa lain stres adalah melebihi kemampuan individu untuk melakukan coping.

\section{Stres Akademik}

Stres yang terjadi di lingkungan sekolah atau pendidikan biasanya disebut dengan stres akademik (Sinaga, M. A. J. 2015; Rahmadani, C. S. M. 2014; Hikmah, Y. 2014; ). Desmita (2010) menyatakan "Stres akademik adalah stres yang disebabkan oleh academic stresor". Academic stresor adalah stres yang dialami siswa yang bersumber dari proses pembelajaran atau hal-hal yang berhubungan dengan kegiatan belajar seperti: tekanan untuk naik kelas, lama belajar, mencontek, banyak tugas, mendapat nilai ulangan, keputusan menentukan jurusan atau karier serta kecemasan ujian dan manajemen stres.

Sejalan dengan pendapat di atas, Rahmawati (2012) menyatakan bahwa stres akademik adalah suatu kondisi atau keadaan di mana terjadi ketidaksesuaian antara tuntutan lingkungan dengan sumber daya aktual yang dimiliki siswa sehingga mereka semakin terbebani oleh berbagai tekanan dan tuntutan. (Alvin 2001; Mubarokah, L. 2015; Sandra, R., \& Ifdil, I. (2015) juga menyatakan stres akademik adalah stres yang muncul karena adanya tekanan-tekanan untuk menunjukkan prestasi dan keunggulan dalam kondisi persaingan akademik yang semakin meningkat, sehingga mereka semakin terbebani oleh berbagai tekanan dan tuntutan. Selanjutnya, (Bariyyah 2013; Rahmawati, W. K. 2017) menyatakan stres akademik merupakan respon siswa terhadap berbagai tuntutan yang bersumber dari proses belajar mengajar meliputi: (1) tuntutan naik kelas, (2) menyelesaikan banyak tugas, (3) mendapat nilai ulangan yang tinggi, (4) keputusan menentukan jurusan, (5) kecemasan menghadapi ujian, dan (6) tuntutan untuk dapat mengatur waktu belajar.

Berdasarkan berbagai definisi yang dikemukakan di atas, maka dapat diambil kesimpulan bahwa stres akademik adalah tekanan akibat persepsi subjektif terhadap suatu kondisi akademik. Tekanan ini melahirkan respon yang dialami siswa berupa reaksi fisik, perilaku, pikiran, dan emosi yang negatif yang muncul akibat adanya tuntutan sekolah atau akademik.

\section{Faktor-faktor yang Mempengaruhi Stres Akademik}

Adapun faktor-faktor yang dapat mempengaruhi stres akademik, menurut (Puspitasari, W. 2013; Gunawati, R., Hartati, S., \& Listiara, A. 2010) yaitu faktor internal dan faktor eksternal. Lebih lanjut dijelaskan sebagai berikut.

\section{Faktor internal yang mengakibatkan stres akademik \\ Pola pikir}

Individu yang berpikir tidak dapat mengendalikan situasi, cenderung mengalami stres lebih besar. Semakin besar kendali bahwa ia dapat melakukan sesuatu, semakin kecil kemungkinan stres yang akan dialami siswa. 


\section{Kepribadian}

Kepribadian seorang siswa dapat menentukan tingkat toleransinya terhadap stres. Tingkat stres siswa yang optimis biasanya lebih kecil dibandingkan siswa yang sifatnya pesimis.

\section{Keyakinan}

Penyebab internal selanjutnya yang turut menentukan tingkat stres siswa adalah keyakinan atau pemikiran terhadap diri. Keyakinan terhadap diri memainkan peranan penting dalam menginterpretasikan situasi-situasi di sekitar individu. Penilaian yang diyakini siswa dapat mengubah pola pikirnya terhadap suatu hal bahkan dalam jangka panjang dapat membawa stres secara psikologis.

\section{Faktor eksternal yang mengakibatkan stres akademik Pelajaran lebih padat}

Kurikulum dalam sistem pendidikan standarnya semakin lebih tinggi. Akibatnya persaingan semakin ketat, waktu belajar bertambah, dan beban siswa semakin meningkat. Walaupun beberapa alasan tersebut penting bagi perkembangan pendidikan dalam negara, tetapi tidak dapat menutup mata bahwa hal tersebut menjadikan tingkat stres yang dihadapi siswa meningkat.

\section{Tekanan untuk berprestasi tinggi}

Para siswa sangat ditekan untuk berprestasi dengan baik dalam ujian-ujian mereka. Tekanan ini terutama datang dari orangtua, keluarga, guru, tetangga, teman sebaya, dan diri sendiri.

\section{Dorongan status sosial}

Pendidikan selalu menjadi simbol status sosial. Orang-orang dengan kualifikasi akademik tinggi akan dihormati masyarakat dan yang tidak berpendidikan tinggi akan dipandang rendah. Siswa yang berhasil secara akademik sangat disukai, dikenal, dan dipuji oleh masyarakat. Sebaliknya, siswa yang tidak berprestasi di sekolah disebut lambat, malas atau sulit. Mereka dianggap sebagai pembuat masalah, cenderung ditolak oleh guru, dimarahi orangtua, dan diabaikan teman-teman sebayanya.

\section{Orangtua saling berlomba}

Pada kalangan orangtua yang lebih terdidik dan kaya informasi, persaingan untuk menghasilkan anakanak yang memiliki kemampuan dalam berbagai aspek juga lebih keras. Seiring dengan perkembangan pusatpusat pendidikan informal, berbagai macam program tambahan, kelas seni rupa, musik, balet, dan drama yang juga menimbulkan persaingan siswa terpandai, terpintar, dan serba bisa.

Berdasarkan penjelasan sebelumnya, dapat disimpulkan bahwa faktor-faktor yang mempengaruhi stres akademik yaitu faktor internal yang meliputi pola pikir, kepribadian, dan keyakinan, sedangkan faktor eksternal yang terdiri dari tekanan untuk berprestasi tinggi, dorongan status sosial, pelajaran lebih padat, dan orangtua saling berlomba.

\section{Gejala-gejala Stres Akademik}

Individu yang mengalami stres akan menunjukkan gejala emosional dan fisik (Hernawati, N. 2006; Inayatillah, V. 2015). Lebih lanjut dijelaskan sebagai berikut.

\section{Gejala emosional}

Siswa yang mengalami stres akademik secara emosional ditandai dengan: gelisah atau cemas, sedih atau depresi karena tuntutan akademik, dan merasa harga dirinya menurun atau merasa tidak mampu untuk melaksanakan tuntutan dari pendidikan atau akademik.

\section{Gejala fisik}

Siswa yang mengalami stres akademik secara fisik ditandai dengan: sakit kepala, pusing, tidur tidak teratur, susah tidur, sakit punggung, mencret, lelah atau kehilangan energi untuk belajar. Menurut (Simbolon, I. 2015; Fahmi, F. 2011) gejala stres terdiri atas fisik, emosi, dan ditambah dengan perilaku, lebih lanjut dijelaskan sebagai berikut:

\section{Gejala fisik}

Gejala yang termasuk kategori fisik yaitu: sakit kepala, jantung berdebar-debar, perubahan pola makan lemah atau lemas, sering buang air kecil, dan sulit menelan. 


\section{Gejala emosi}

Gejala emosi antara lain: depresi, cepat marah, murung, cemas, khawatir, mudah menangis, gelisah terhadap hal-hal yang kecil, panik, dan berperilaku implusif.

\section{Gejala perilaku}

Gejala perilaku seperti: dahi berkerut, tindakan agresif, kecenderungan menyendiri, ceroboh, menyalahkan orang lain, melamun, gelak tawa gelisah bernada tinggi, berjalan mondar-mandir, dan perilaku sosial yang berubah.

\section{Respon terhadap Stres Akademik}

Reaksi terhadap stresor akademik terdiri dari pikiran, prilaku, reaksi tubuh, dan perasaan (Rahmadani, C. S. M. 2014; Olejnik \& Holschuh 2007). Lebih lanjut dijelaskan sebagai berikut:

\section{Pemikiran}

Respon yang muncul dari pemikiran, seperti: kehilangan rasa percaya diri, takut gagal, sulit berkonsentrasi, cemas akan masa depan, melupakan sesuatu, dan berpikir terus-menerus mengenai apa yang seharusnya mereka lakukan.

\section{Perilaku}

Respon yang muncul dari perilaku, seperti: menarik diri, menggunakan obat-obatan dan alkohol, tidur terlalu banyak atau terlalu sedikit, makan terlalu banyak atau terlalu sedikit, dan menangis tanpa alasan.

\section{Reaksi tubuh}

Respon yang muncul dari reaksi tubuh, seperti: telapak tangan berkeringat, kecepatan jantung meningkat, mulut kering, merasa lelah, sakit kepala, rentan sakit, mual, dan sakit perut.

\section{Perasaan}

Respon yang muncul dari perasaan, seperti: cemas, mudah marah, murung, dan merasa takut.

Adapun respon lain terhadap stres akademik menurut Barriyah (2013) adalah respon seseorang terhadap berbagai tuntutan pada dirinya yang tidak menyenangkan dan dipersepsikan individu sebagai stimulus yang membahayakan serta melebihi kemampuan individu tersebut untuk melakukan coping sehingga individu tersebut bereaksi baik secara fisik, emosi, maupun perilaku. Tuntutan yang bersumber dari proses belajar meliputi: tuntutan menyelesaikan banyak tugas, tuntutan mendapat nilai tinggi, kecemasan menghadapi ujian, dan manajemen waktu.

Berdasarkan penjelasan di atas, dapat disimpulkan bahwa terdapat respon stres akademik yaitu fisik, emosi, dan perilaku.

\section{SIMPULAN DAN SARAN}

Stres akademik bukan hal baru dari permasalah siswa, namun upaya intensif untuk pengelolaan stres akademik siswa sepertinya tidak banyak dilakukan di Indonesia, kondisi ini terlihat dari tidak banyaknya penelitian tentang stres akademik. Hal ini disebabkan belum bayak riset berkenaan dengan stres akademik siswa.

Semoga kedepannya peningkatan, pengembangan dan optimalisasi layanan bimbingan dan konseling untuk pengelolaan stres akademik dapat terselenggara, perlunya layanan bimbingan dan konseling untuk menurunkan level stres yang dialami siswa. Siswa dapat memperoleh bantuan untuk mengelola stres yang dialaminya, sehingga fungsinya sebagai siswa dapat di optimalkan.

\section{DAFTAR RUJUKAN}

Adawiyah, R. 2017. Analisis tingkat stres mahasiswa dalam menghadapi penyusunan skripsi.

Alvin, N.O. 2001. Handling Study Stress: Panduan agar anda bisa belajar bersama anak-anak anda. Jakarta: Elex Media Komputindo.

Anggola, J.E., \& Ongori, H. 2009. "An Asessment of Academic Stress Among Undergraduate Students: The case of university of botswana". Educational research and reviews, 4 (2): 063-070. 
Azhar, A. 2015. Hubungan antara Stres Sekolah dan Locus of Control dengan Prokrastinasi Akademik (Doctoral dissertation, Universitas Muhammadiyah Surakarta).

Bariyyah, K. 2013. "Menurunkan Tingkat Stres Akademik Siswa dengan Teknik Cognitive-Behavioral Stres Management". Proseding Kongres XII, Konvensi XVIII Asosiasi Bimbingan dan Konseling Indonesia dan Seminar Internasiol Konseling. Denpasar Bali, 14-16 November.

Calaguas, G. M. 201). Collage Academic Stress: Differences along Gender Lines. Journal of Social and Developmental Sciences, 1(5), 194-201.

Dari, P. T. S. D., \& Ibu, D. S. 2012. Perbedaan tingkat stres ditinjau dari empty nest syndrome dan status ibu.

Desmita. 2010. Psikologi Perkembangan Peserta Didik. Bandung: Remaja Rosdakarya.

Diponegoro, A. M., \& Thalib, S. B. 2001. Meta-Analisis tentang Perilaku Koping Prevenstif dan Stres. Psikologika: Jurnal Pemikiran dan Penelitian Psikologi, 6(12).

Ernawati, L., \& Rusmawati, D. 2015. Dukungan Sosial Orang Tua dan Stres Akademik pada Siswa SMK yang Menggunakan Kurikulum 2013. Jurnal Empati, 4(4), 26-31.

Fahmi, F. 2011. Hubungan Antara Self-Efficacy dengan Stres Akademik Pada Mahasiswa (Doctoral dissertation, Prodi Psikologi UNIKA Soegijapranata).

Garniwa, I. 2007. Pengaruh stress kerja terhadap motivasi serta dampaknya terhadap prestasi kerja sdosen tetap universitas widyatama.

Gunawati, R., Hartati, S., \& Listiara, A. 2010. Hubungan antara efektivitas komunikasi mahasiswa-dosen pembimbing utama skripsi dengan stres dalam menyusun skripsi pada mahasiswa Program Studi Psikologi Fakultas Kedokteran Universitas Diponegoro. Jurnal Psikologi Undip, 3(2), 93-115.

Hernawati, N. 2006. Tingkat stres dan strategi koping menghadapi stres pada mahasiswa Tingkat Persiapan Bersama tahun akademik 2005/2006. Jurnal Ilmu Pertanian Indonesia, 11(2), 43-49.

Hidayat, B. U. A. 2012. Bungan Tingkat Stres dengan Kejadian Insomnia pada Mahasiswa Program Studi Ilmu Keperawatan Universitas Diponegoro (Doctoral dissertation, Diponegoro University).

Hikmah, Y. 2014. Pengaruh Layanan Konseling Kelompok Eklektik Dalam Mengurangi Stress pada Anak Berprestasi Belajar Tinggi Siswa Kelas Xi Sma Negeri 8 Medan Tahun Ajaran 2014/2015 (Doctoral dissertation, UNIMED).

Inayatillah, V. 2015. Hubungan antara adversity quotient dengan kecenderungan stres dalam menyelesaikan tugas akhir (penulisan skripsi) pada mahasiswa (Doctoral dissertation, UIN Sunan Ampel Surabaya).

Misra, R., \& Castillo, L.G. 2004. "Academic Stress Among College Students: Comparison of american and international students”. International Journal of Stress Management, 16 (1): 2-14.

Mubarokah, L. 2015. Gambaran Koping Stres remaja dengan Orang Tua Bercerai di SMA Muhammadiyah 3 Yogyakarta Tahun 2010 (Doctoral dissertation, STIKES'Aisyiyah Yogyakarta).

Muharrifah, A. 2009. Interaksi antara Remaja, Ayah, dan Sekolah Serta Hubungannya dengan Tingkat Stres dalam Menghadapi Ujian Nasional (Doctoral dissertation).

Pratama, M. R. 2015. Hubungan Motivasi Akademik dengan Tingkat Stres Akademik Mahasiswa Keperawatan Semester VI Stikes 'Aisyiyah Yogyakarta (Doctoral dissertation, STIKES'Aisyiyah Yogyakarta).

Puspitasari, W. 2013. Hubungan antara Manajemen Waktu dan Dukungan Sosial dengan Prestasi Akademik Mahasiswa yang Bekerja. EMPATHY Jurnal Fakultas Psikologi, 2(1).

Rahmadani, C. S. M. 2014. Hubungan antara Sense of Humor dengan Stress Akademik pada Siswa Kelas Akselerasi SMA Negeri 1 Bireun (Doctoral dissertation, Universitas Medan Area).

Rahmawati, D. D. 2012. Pengaruh Self-Efficacy terhadap Stres Akademik pada Siswa Kelas 1 Rintisan Sekolah Bertaraf Internasional (RSBI) di SMP Negeri 1 Medan. Pengaruh Self-Efficacy terhadap Stres Akademik pada Siswa Kelas 1 Rintisan Sekolah Bertaraf Internasional (RSBI) di SMP Negeri 1 Medan.

Rahmawati, W. K. 2017. Efektivitas Teknik Restrukturisasi Kognitif untuk Menangani Stres Akademik Siswa. Jurnal Konseling Indonesia, 2 (1 Oktober).

Sandra, R., \& Ifdil, I. (2015). Konsep Stres Kerja Guru Bimbingan dan Konseling. Jurnal EDUCATIO: Jurnal Pendidikan Indonesia, 1(1), 80-85.

Santrock, J. W. 2007. Psikologi Pendidikan. Terjemahan oleh Tri Wibowo B.S. Jakarta: Kencana Perdana Media Group.

Sarafino, E. P. 2006. Health Psychology: Biopsychosocial interactions. Fifth.

Sayekti, E. 2017. Efektifitas Teknik Self-Instruction dalam Mereduksi Stress Akademik pada Siswa Kelas XI MA YAROBI Kec. Grobogan, Kab. Grobogan Tahun 2016/2017 (Doctoral dissertation, IAIN Salatiga).

Simbolon, I. 2015. Reaksi stres akademis mahasiswa keperawatan dengan sistem belajar blok di fakultas keperawatan x bandung. Jurnal Skolastik Keperawatan, 1(01). 
Sinaga, M. A. J. 2015. Stres Akademik antara Anak Taman Kanak-kanak yang Mendapat Pengajaran Membaca dan Tidak Mendapat Pengajaran Membaca (Doctoral dissertation, Program Studi Psikologi FPSI-UKSW).

Siska, M. 2011. Hubungan Efikasi Diri dengan Stres Mahasiswa yang Sedang Mengerjakan Skripsi pada Mahasiswa UIN SUSKA Riau Pekanbaru (Doctoral dissertation, Universitas Islam Negeri Sultan Syarif Kasim Riau).

Sutjiato, M. 2015. Hubungan Faktor Internal dan Eksternal dengan Tingkat Stress pada Mahasiswa Fakultas Kedokteran Universitas Sam Ratulangi Manado. JIKMU, 5(1).

Taufik, T., Ifdil, I., \& Ardi, Z. (2013). Kondisi Stres Akademik Siswa SMA Negeri di Kota Padang. Jurnal Konseling dan Pendidikan, 1(2), 143-150.

Thursan, H. 2005. Belajar Secara Efektif. Jakarta: Puspa Swasta.

Wardi, R., \& Ifdil, I. (2016). Stress Conditions In Students Completing Thesis. GUIDENA: Jurnal Ilmu Pendidikan, Psikologi, Bimbingan dan Konseling, 6(2), 190-194. 